\title{
Synthesis and stereochemical determination of an antiparasitic pseudo-aminal type monoterpene indole alkaloid
}

\author{
Yoshihiko Noguchi ${ }^{1,2} \cdot$ Tomoyasu Hirose $^{1,2} \cdot$ Aki Ishiyama $^{1,2} \cdot$ Masato Iwatsuki $^{1,2}$. \\ Kazuhiko Otoguro $^{1} \cdot$ Toshiaki Sunazuka $^{1,2} \cdot$ Satoshi Ōmura $^{1}$
}

Received: 25 April 2016/Accepted: 14 May 2016/Published online: 21 June 2016

(c) The Author(s) 2016. This article is published with open access at Springerlink.com

\begin{abstract}
Nor stemmadenine alkaloids, isolated from the genus Tabernaemontana, display a range of bioactivity. 16-Hydroxy-16,22-dihydroapparicine, the active component of an extract from the Tabernaemontana sp. (dichotoma, elegans, and divaricate), exhibited potent antimalarial activity, representing the first such report of the antimalarial property of 5-nor stemmadenine alkaloids. $\mathrm{We}$, therefore, decided to attempt the total synthesis of the compound to explore its antimalarial activity and investigate structure and bioactivity relationships. As a result, we completed the first total synthesis of 16-hydroxy-16,22dihydroapparicine, by combining a phosphine-mediated cascade reaction, diastereoselective nucleophilic addition of 2-acylindole or methylketone via a Felkin-Anh transition state, and chirality transferring intramolecular Michael addition. We also clarified the absolute stereochemistries of the compound. Furthermore, we evaluated the activity of the synthetic compound, as well as that of some intermediates, all of which showed weak activity against chloroquine-resistant Plasmodium falciparum (K1 strain) malaria parasites.
\end{abstract}

Keywords 5-Nor stemmadenine alkaloid - Antimalarial agent $\cdot$ Pseudo-aminal type structure $\cdot$ Iminophosphorane

Toshiaki Sunazuka

sunazuka@lisci.kitasato-u.ac.jp

Satoshi Ōmura

omuras@insti.kitasato-u.ac.jp

1 Kitasato Institute for Life Sciences, Kitasato University, 5-91 Shirokane, Minato-ku, Tokyo 108-8641, Japan

2 Graduate School of Infection Control Sciences, Kitasato University, 5-9-1 Shirokane, Minato-ku, Tokyo 108-8641, Japan mediated cascade reaction $\cdot$ Chirality transfer intramolecular Michael reaction - Diastereoselective 1,2-addition using indole nucleophile

\section{Introduction}

Naturally occurring chemicals represent a treasure trove of compounds which hold promise as the seeds of discovery for drugs and medicines and which may facilitate the elucidation of structure and function investigations of bioactivity [1]. Ōmura's research group at the Kitasato Institute is a global pioneer in the search for bioactive agents that may be of use in developing drugs and medicines to fight to infection and combat tropical diseases (such as the filariases, malaria, trypanosomiasis, etc.), all originating from microbial metabolites. At present, 483 new compounds have been discovered, 26 of which have become useful, widely used agents in human and animal health, including the ground-breaking avermectins [2].

Malaria is one of the world's worst health and socioeconomic problems, causing widespread death, disease, disability, and economic loss. Infection arises when a protozoal parasite of the Plasmodium genus is transmitted to humans via the bites of blood-feeding mosquitoes. Plasmodium falciparum parasites cause the most deadly form of the disease, which can cause death in a few days, especially if cerebral malaria develops. Generally, most deaths occur in children under 5 years old, although deaths have been reduced markedly by recent global initiatives to tackle the disease [3-5]. Commonly used drugs to combat malaria include quinine, chloroquine, mefloquine, halofantrine, and sulfadoxine/pyrimethamine (Fig. 1). However, drug resistance in parasites has usually developed quickly, rendering many of these drugs useless, preventing 
Fig. 1 Therapeutic drugs for malaria

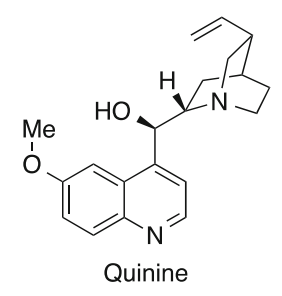<smiles>CCN(CC)CCCC([N+]#N)Nc1ccnc2cc(Cl)ccc12</smiles>

Chloroquine

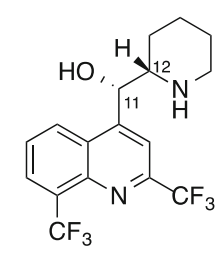

(+)-(11S, 12R)-Mefloquine

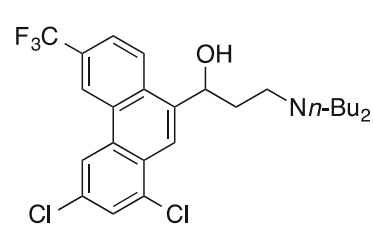

Halofantrine

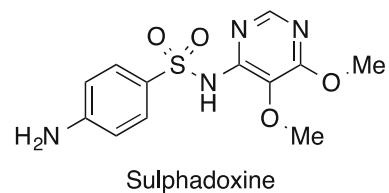

Sulphadoxine<smiles>CCc1nc(N)nc(N)c1-c1ccc(Cl)cc1</smiles>

Pyrimethamine

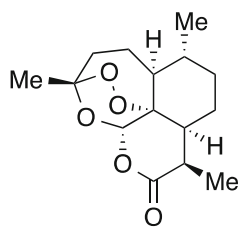

Artemisinin

Table 1 Antimalarial activity and cytotoxicity of Tabernaemontana dichotoma extract

\begin{tabular}{|c|c|c|c|c|c|}
\hline & \multicolumn{5}{|c|}{$\mathrm{IC}_{50}(\mu \mathrm{g} / \mathrm{mL})$} \\
\hline & \multicolumn{2}{|c|}{ Antimalarial activity } & \multirow{2}{*}{$\begin{array}{l}\text { Cytotoxicity } \\
\text { MRC-5 }\end{array}$} & \multicolumn{2}{|c|}{ Selectivity index (SI) } \\
\hline & $\mathrm{K} 1^{\mathrm{a}}$ & $\mathrm{FCR}^{\mathrm{b}}$ & & $\mathrm{M} / \mathrm{K}^{\mathrm{c}}$ & $\mathrm{M} / \mathrm{F}^{\mathrm{d}}$ \\
\hline Tabernaemontana dichotoma $\mathrm{MeOH}$ extract & 0.59 & 0.35 & $>25.0$ & $>42.4$ & $>71.4$ \\
\hline Artemisinin & 0.006 & 0.006 & 45.2 & 7528 & 7528 \\
\hline
\end{tabular}

${ }^{a}$ Chloroquine-resistant strain

${ }^{\mathrm{b}}$ Chloroquine-sensitive strain

c MRC-5/K1

${ }^{d}$ MRC-5/FCR3

effective treatment and hindering disease elimination efforts. In 1972, Professor Tu Youyou discovered artemisinin to be the active ingredient in the plant Artemisia апnиa, which was commonly used in China to treat fever. Artemisinin derivatives became the most effective therapeutic drugs against malaria [6]. The World Health Organization (WHO) recommends artemisinin-based combination therapies (ACTs) for malaria treatment [7], a multidrug approach requiring the use of artemisinin together with other drugs to help offset the pace of drug resistance to artemisinin developing and spreading. ACTs are already compromised because the safety of artemisinin with regard to use during first trimester pregnancy is yet to be established and, worse, resistance to artemisinin derivatives developed almost immediately in locations along the Thai-Cambodian border [8-11]. Therefore, inexpensive and potent antimalarial drugs, especially those that have different modes of action, are urgently required on a probably continuing basis due to the ability of the malaria parasites to quickly develop drug resistance.

Many of the therapies currently in development use known antimalarial pharmacophores (e.g., aminoquinolines and/or peroxides), which have been chemically modified to overcome the failures of their predecessors [12]. Although these compounds have been important in the treatment of malaria, it would be highly advantageous to discover chemotypes with novel action mechanisms [13]. However, despite important advances in our understanding of the Plasmodium genome, the identification and validation of new drug targets have been challenging [14-16].

16-Hydroxy-16,22-dihydroapparicine (1), a known 5-nor stemmadenine alkaloid, was identified at the Kitasato Institute as a main component of a leaf's $\mathrm{MeOH}$ extract from the plant Tabernaemontana dichotoma, which displayed antimalarial properties. The potent antimalarial activity of the complex leaf extract against chloroquineresistant Plasmodium falciparum (K1 strain) parasites in vitro, and its moderate selectivity (against MRC-5 strain human cells) are summarized in Table 1. Natural compound 1 was originally isolated from a leaf of Tabernaemontana dichotoma in 1984 by the Verpoorte group [17] (Fig. 2). The relative structural determination of $\mathbf{1}$ was based on detailed NMR study, yet the absolute stereochemistry was not determined. As $\mathbf{1}$ has the potential to contain antimalarial activity, we decided to attempt the total synthesis of $\mathbf{1}$ to confirm its stereochemistry and investigate its antimalarial effect.

In this review, the total synthesis, stereochemical determination, and antimalarial activity of 16-hydroxy16,22-dihydroapparicine are discussed [18, 19]. 
Fig. 2 Structure of $(15 S, 16 S)$ 16-hydroxy-16,22-

dihydroapparicine (1)
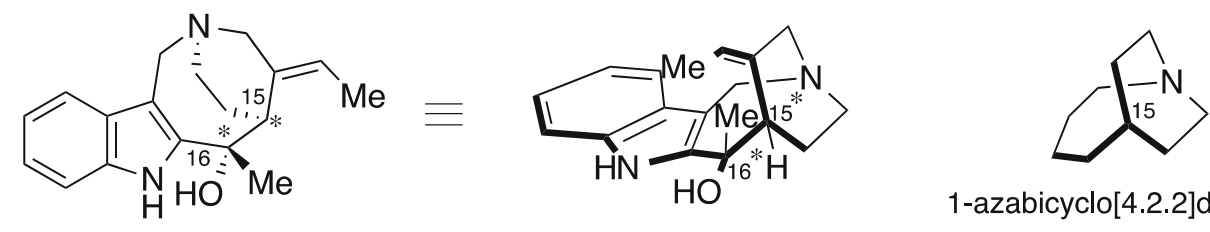

1-azabicyclo[4.2.2]decane

(15S*,16S*)-16-hydroxy-16,22-dihydroapparicine (1) (proposed stereochemistry)

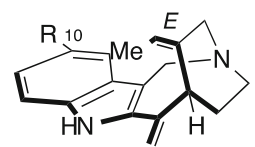

Apparicine (2) $\mathrm{R}=\mathrm{H}$ 10-Hydroxyapparicene (3) $(\mathrm{R}=\mathrm{OH})$ 10-Methoxyapparicine (4) $(\mathrm{R}=\mathrm{OMe})$

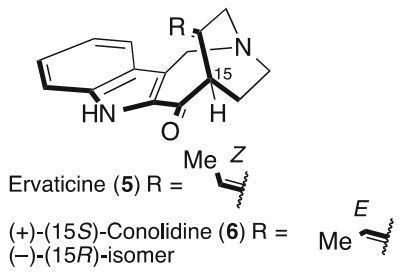

$(+)-(15 S)-$-Conolidine
$(-)-(15 R)$-isomer

synthesis of the pseudo-aminal type indole alkaloids, such as apparicine (2), using Potier's expected biomimetic oxidative transformation from pericine (7) (Scheme 1).

Fig. 3 Structure of apparicine (2) and related compounds

Naturally occurring compound $\mathbf{1}$ has the same framework as Apparicine (2), the first 5-nor stemmadenine alkaloid discovered, which was isolated from Aspidosperma dasycarpon more than 45 years ago $[20,21]$ (Fig. 3). There are currently 22 known 5-nor stemmadenine alkaloid compounds [22-32], with the compounds exhibiting a wide range of biological activity, including being antimicrobial [33-35] and antibacterial (antituberculoid) [32], as well as displaying opioid properties [36]. Consequently, these alkaloids are of considerable interest. The main structural feature of the alkaloids is the strained 1-azabicyclo[4.2.2]decane skeleton, including a single carbon connection, between the indole 3-position and aliphatic nitrogen moiety, which is a defining characteristic of these compounds. The relative stereochemistry of 2-5 has also been reported for conolidine (6), the completed asymmetric total synthesis being accomplished by Micalizio's group [37].

\section{Proposed biosynthesis}

The special architecture involved, embodying a 1-azabicyclo[4.2.2]decane, is probably the result of the C-5 tryptamine atom being excised from the alkaloid stemmadenine by a retro-Mannich reaction. Some in vitro transformations of stemmadenine-type to 5-nor stemmadenine-type alkaloids have provided further support for this biogenetic model, which the following summarizes.

Kutney and co-workers reported the biosynthesis of the 1-azabicyclo[4.2.2]decane structure in the 5-nor stemmadenine alkaloids 50 years ago, using incorporated radioisotope experiments on the plant Aspidosperma pyricollum. Later, Lim and co-workers [38] reported partial

Due to their unique structure and potentially useful biological activity, the total synthesis of 5-nor stemmadenine alkaloids has been reported by Bennasar et al. [39, 40], Micalizio [37], and Takayama [41] (Scheme 2). In addition, synthetic work on the 1-azabicyclo[4.2.2]decane skeleton core has been published by Joule [42, 43] and Weinreb's group [44] (Scheme 3). A recent report of the total synthesis of $( \pm$ )-apparicine (2) by Bennasar and coworkers [39, 40] detailed an approach which utilized an intramolecular Heck reaction. Micalizio and Takayama $[37,41]$ reported the total syntheses of conolidine $(\mathbf{6})$, which could be derived from an iminium ion under intramolecular Mannich reaction. In addition, Micalizio and co-workers [37] clarified the absolute stereochemistry of 6 .

In 1977, Joule and co-workers [42, 43] reported the synthesis of apparicine, detailing an approach to $\mathbf{2}$ which utilizes an intramolecular Mannich cyclization to construct the 1-azabicyclo[4.2.2]decane skeleton. Weinreb's group [44] reported the construction of a 4-cyclic compound $\mathbf{1 7}$ using nitrosoalkene and indole in 2014.

Our synthetic approach used a distinctive reaction based on the hypothesis that the main structural feature of these alkaloids is the strained 1-azabicyclo[4.2.2]decane skeleton, including a single carbon connection between the indole 3-position and aliphatic nitrogen moiety, which is a gramine-type (or vinamidine-type) moiety (Fig. 4). This structure has a "push-pull" nature, which is stabilized by electron-donating or electron-withdrawing groups. For example, the aliphatic carbon-nitrogen bond of the gramine type (or vinamidine type) is easily cleaved by retroMannich reaction under acid [45], base [46-48], and thermal [49] conditions, and with various reagents (e.g., trialkylphosphine [50-55], Lewis acid [56], phthalimide [57], thiol $[58,59]$, and activated ester $[60,61])$ to generate the indolinium cation. We, therefore, anticipated that the 


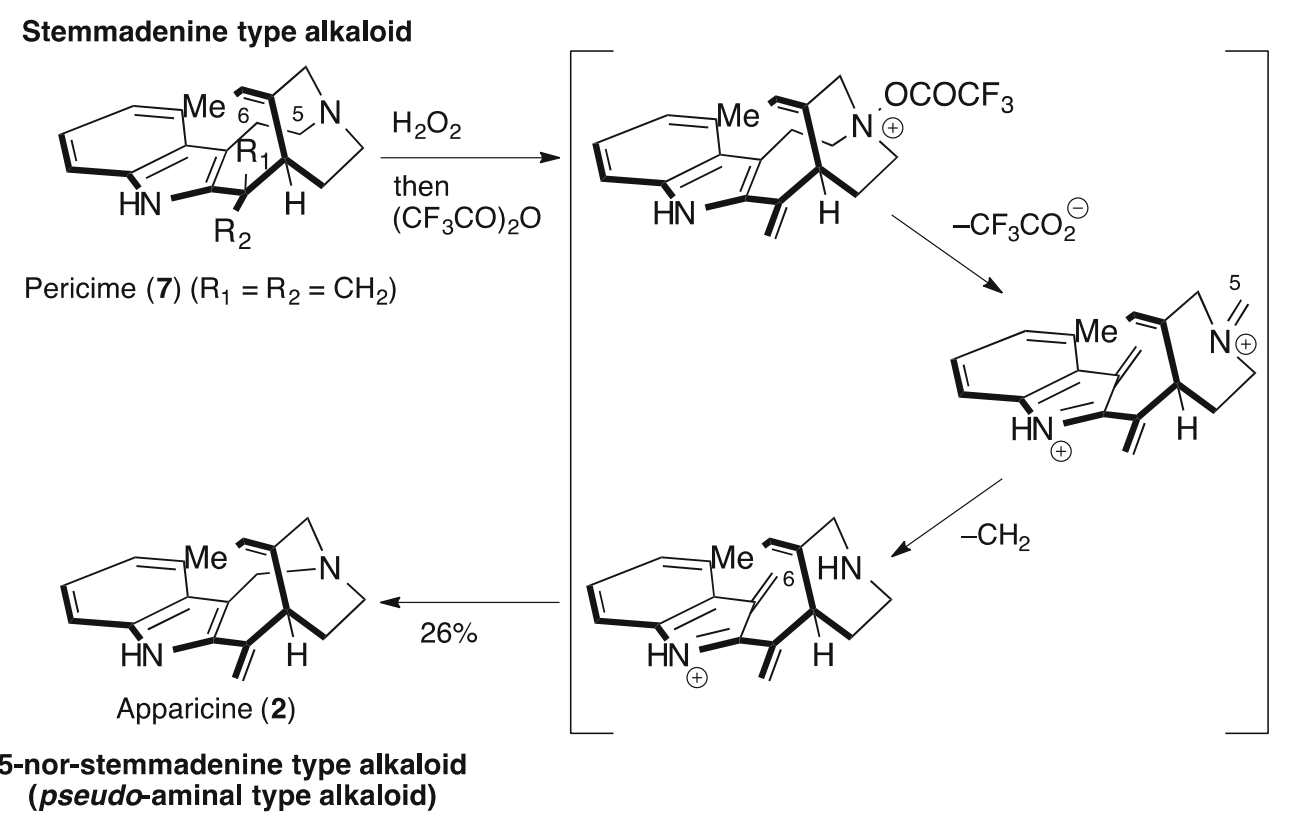

Scheme 1 Biomimetic transformation

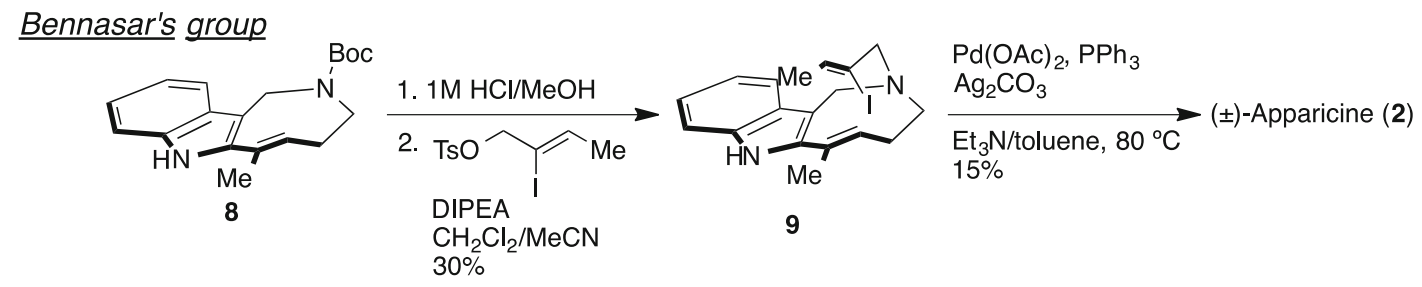

Micalizio's group

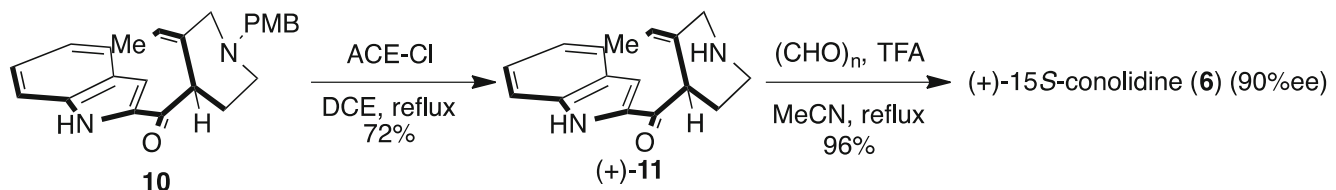

Takayama's group

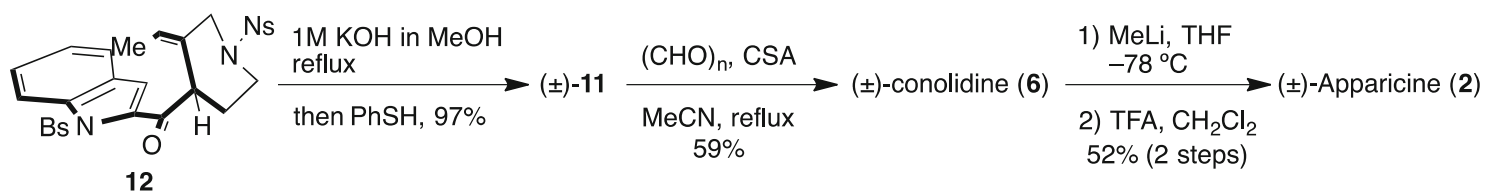

Scheme 2 Reported total synthesis of apparicine and conolidine

propendiamine moiety was an indicator of reactivity similar to the aminal, leading us to suppose the framework as a "pseudo-aminal type structure".

To complete the total synthesis of $\left(15 S^{*}, 16 S^{*}\right)$-16-hydroxy-16,22-dihydroapparicine (1), we designed a novel phosphineimine-mediated cascade reaction, without any isolated unstable intermediate (Scheme 4). The cascade reaction sequence was: (1) Staudinger reaction of an azide 21 with triphenylphosphine to generate phosphineimine intermediate 20 [62]; (2) intramolecular N-allylation of phosphineimine transformed into aminophosphinium 19 [63-65]; (3) aza-Wittig reaction of 19 with formaldehyde; and (4) intramolecular Mannich reaction; nucleophilic attack might be performed from the indole 3-position to iminium cation 18. We needed to solve two challenging issues. Firstly, the N-allylation of the phosphineimine group; phosphineimine has relatively high nucleophilicity, while the leaving group involves sufficient electrophilicity. 
Joule's group

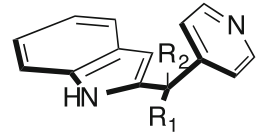

13

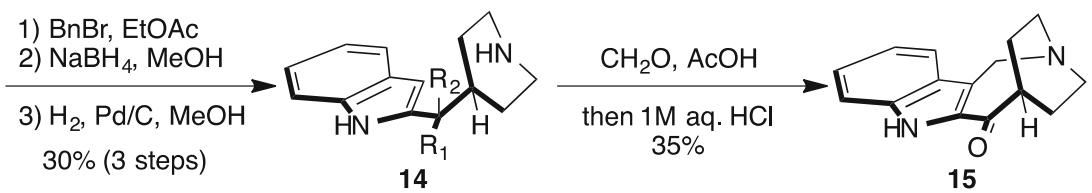

$\mathrm{R}_{1}=\mathrm{R}_{2}=-\mathrm{OCH}_{2} \mathrm{CH}_{2} \mathrm{O}-$

$\mathrm{R}_{1}=\mathrm{R}_{2}=-\mathrm{OCH}_{2} \mathrm{CH}_{2} \mathrm{O}-$

\section{Weinreb's group}

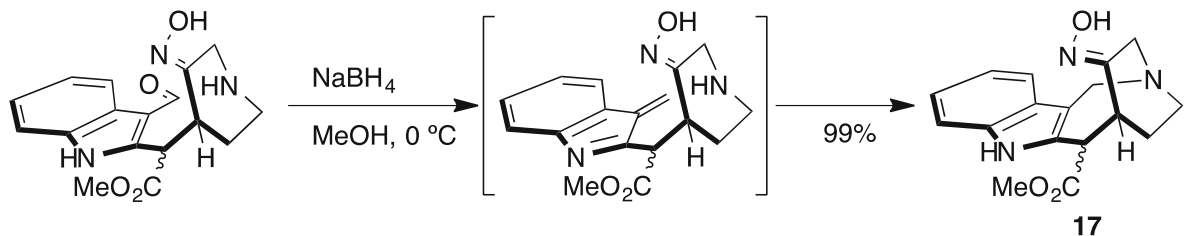

16

Scheme 3 Reported synthetic study of the 1-azabicyclo[4.2.2]decane skeleton

Fig. 4 Gramines (vinamidines) as versatile pseudo-aminal type compounds

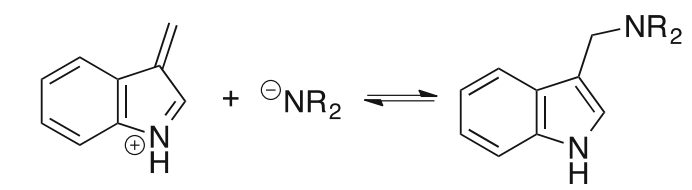

indolinium cation

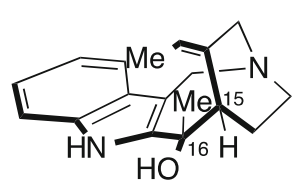

$15 S^{\star}, 16 S^{\star}-1$

(proposed stereochemistry)

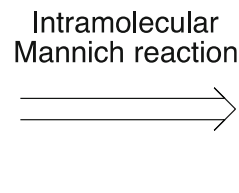

r)
${ }_{\mathrm{R}}^{\mathrm{R}_{2} \mathrm{~N}} \chi_{\mathrm{R}}^{\mathrm{NR}_{2}}=\stackrel{{ }_{\mathrm{R}}}{\mathrm{NR}_{2}}+{ }_{\mathrm{R}}^{\ominus} \mathrm{NR}_{2}$
aminal iminium cation
i


C-16 stereochemistry outcome of the Felkin-Anh transition state [67-71] (Scheme 5). Compound 22 could be constructed with the indole nucleophile and azidoaldehyde $\mathbf{2 3}$.

To construct the C-15 stereocenter, we envisaged a remote stereocontrolled Michael reaction [72] of the $\alpha, \beta$ unsaturated carboxamide $\mathbf{2 5}$ with the crotonic acid derivative.

Synthesis of the azidoaldehyde $\mathbf{2 3}$ began from commercially available cis-butenediol, to afford (-)-25 [73] (Scheme 6). With the Michael accepter in hand, we attempted the remote stereocontrolled Michael reaction of (-)-25, with only minor success, (-)-25 appearing with no stereoselection and in low yield, along with $\gamma$-adduct as an undesired product. Subsequently, olefin isomerization afforded the unsaturated $E$-olefin $\mathbf{2 4}$ as a 1:1 diastereomixture (at C-15). Then, eight steps functionalization provided the azidoaldehyde $( \pm)-\mathbf{2 3}$ in $38 \%$ overall yield.
With the azidoaldehyde $( \pm)-23$ and the $N$-phenylsulfonyl indole 27 [74-81] in hand, we examined the nucleophilic addition, the hydroxyindole $( \pm)$-28 being provided in $85 \%$ yield as a single diastereomer (Scheme 7). Following the oxidation of $( \pm)-\mathbf{2 8}$ to obtain the $( \pm)$-ketoindole, the $N$-phenylsulfonyl and pivaloyl groups were subsequently removed under basic solvolysis to provide the hydroxyketoindole $( \pm)-22$ in $87 \%$ yield. Diastereoselective methylation of $( \pm)-\mathbf{2 2}$ converted it to dihydroxyindole ( \pm )-29 as a single diastereomer in excellent yield. The planar structure of ( \pm -29 was confirmed by HMQC and HMBC studies. We expected the stereoselectivity outcome to be the Felkin-Anh transition state and so sought a suitable leaving group on the allyl alcohol. We eventually discovered a 3-nitropyridyl group [82, 83] as an efficient leaving group, allowing conversion of the 3-nitropyridinylation of $( \pm)$-29 into the cascade reaction precursor

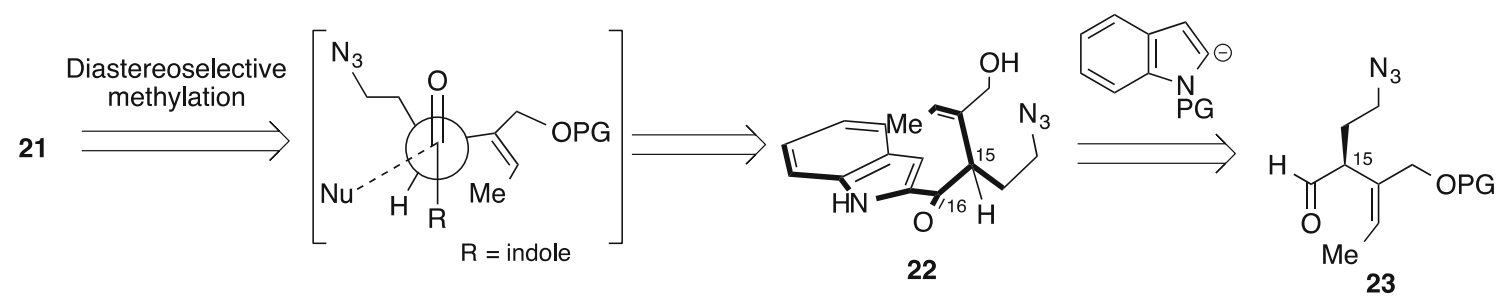

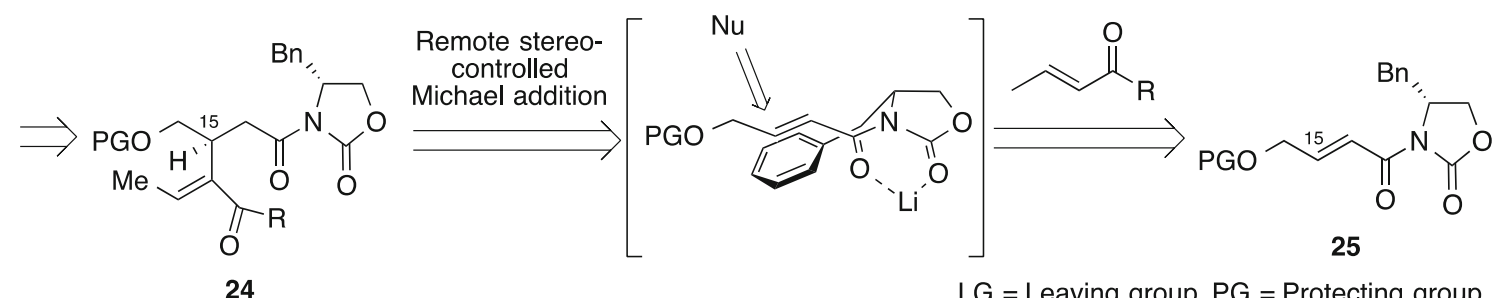

Scheme 5 Retrosynthetic analysis of key intermediate

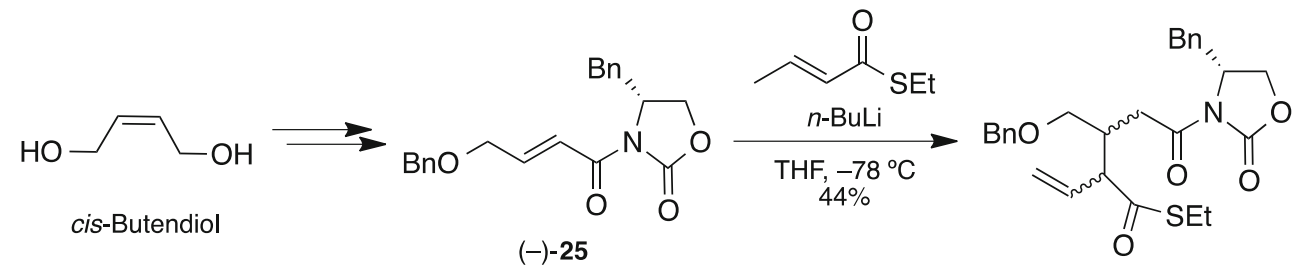

$(-)-25$

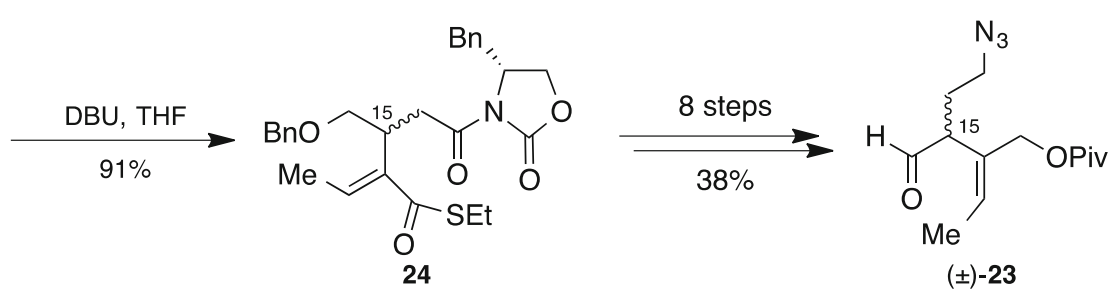

Scheme 6 Synthesis of azidoaldehyde (23) 


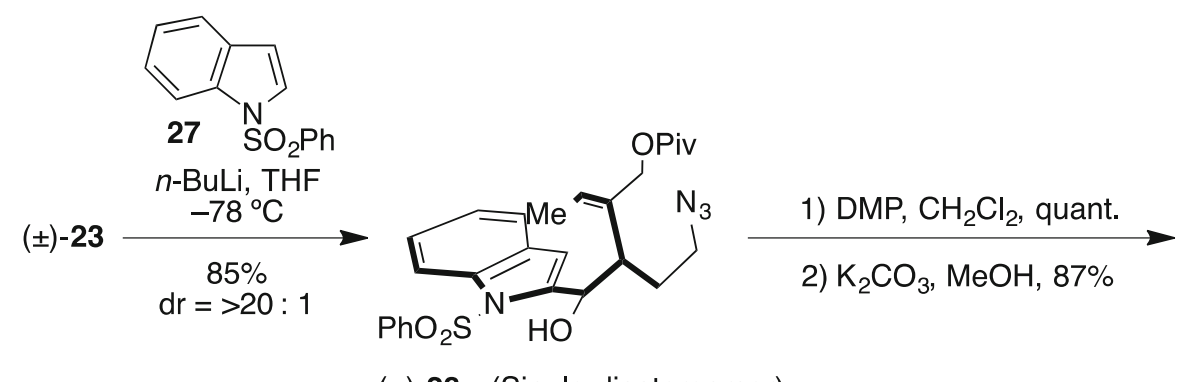

( \pm )-28 (Single diastereomer)

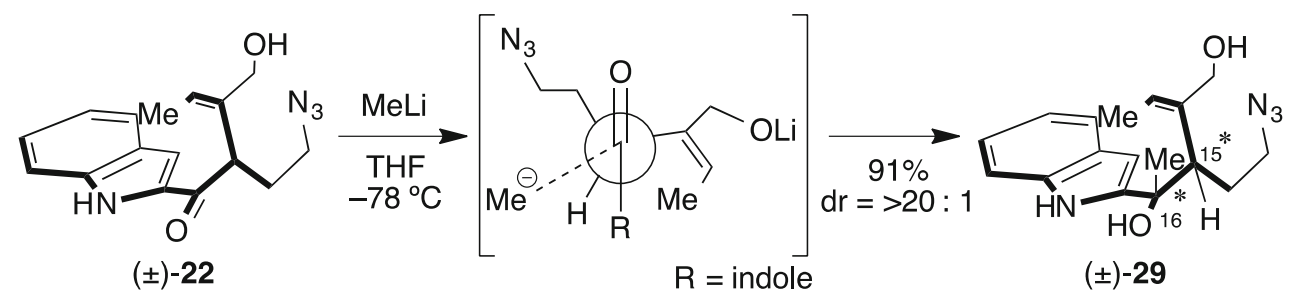

(Single diastereomer)

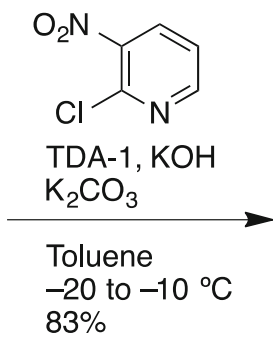

$83 \%$

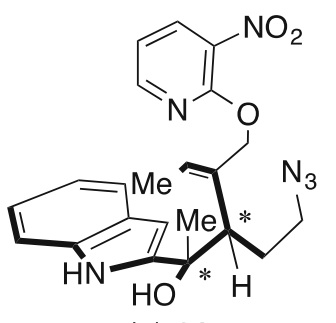

$( \pm)-21$

Scheme 7 Synthesis of proposed hydroxyapparicine (1)

(土)-21 in $93 \%$ yield, using the process reported by Ballesteros and co-workers [84, 85]. We then attempted construction of the 1-azabicyclo[4.2.2]decane skeleton, including the pseudo-aminal moiety. The cascade reaction precursor (土)-21, with $\mathrm{PPh}_{3}$ at $60{ }^{\circ} \mathrm{C}$, generated iminophosphorane, the reaction mixture subsequently being acidified using $\mathrm{AcOH}$ for activation of the 3-nitropyridyl group. Finally, formaldehyde and PPTS were added to the reaction mixture to convert the iminophosphonium cation, followed by a Mannich reaction to furnish (土)-1 in $88 \%$ yield. The relative stereochemistry was confirmed by ROESY correlations (Fig. 5).

\section{Structure determination}

However, the spectral data of synthetic $( \pm)-\mathbf{1}$ did not agree with that of naturally occurring 1 [17]. In particular, analysis of synthetic $( \pm)-\mathbf{1}$, showed a ROESY relationship between H-18 or H-19 and 16-Me. Consequently, the relative stereochemistry of synthetic $( \pm)-\mathbf{1}$ was determined to

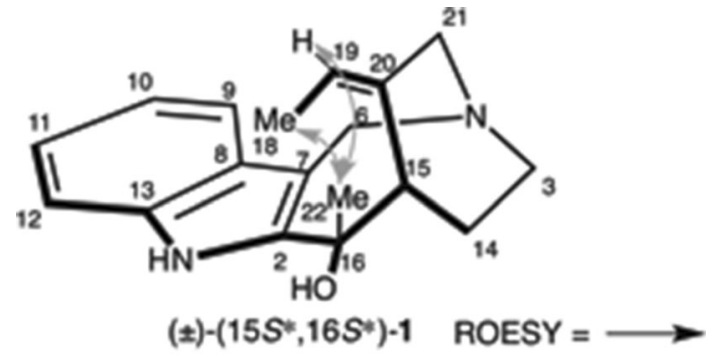

Fig. 5 ROESY observations of synthetic $( \pm)-\left(15 S^{*}, 16 S^{*}\right)-1$

be a $15 S^{*}, 16 S^{*}$-configuration. Data of synthetic $( \pm)$ $\left(15 S^{*}, 16 S^{*}\right)-1$ were then compared with naturally occurring compound (Table 2), with ${ }^{1} \mathrm{H}$ and ${ }^{13} \mathrm{C}$ NMR indicating differences of chemical shift (differences of all positions are shown in the experiment section). In ${ }^{1} \mathrm{H}$ NMR, 16-Me and $\mathrm{H}-6 \alpha, \beta$ signals were registered more than $0.20 \mathrm{ppm}$ and, furthermore, the ${ }^{13} \mathrm{C}$ signals of the piperidine ring were greatly shifted from those seen in natural occurring $\mathbf{1}$. Therefore, we expected that the 16-Me group in naturally 
Table 2 Comparison of the NMR data of synthetic $( \pm)-\left(15 S^{*}, 16 S^{*}\right)$-16-hydroxy-16,22-dihydroapparicine (1) with those reported for the natural product

\begin{tabular}{|c|c|c|c|c|c|c|}
\hline \multirow[t]{2}{*}{ Position } & \multicolumn{3}{|l|}{${ }^{1} \mathrm{HNMR}$} & \multicolumn{3}{|l|}{${ }^{13} \mathrm{CNMR}$} \\
\hline & $\begin{array}{l}\text { Synthetic }( \pm)-\left(15 S^{*}, 16 S^{*}\right)-\mathbf{1}^{\mathrm{a}} \\
\delta_{H} \text { (int., mult, } J \text { in Hz) }\end{array}$ & $\begin{array}{l}\text { Reported } \mathbf{1}^{\mathrm{b}} \\
\delta_{H} \text { (int., mult, } J \text { in } \mathrm{Hz} \text { ) }\end{array}$ & $\Delta \delta^{\mathrm{c}}$ & $\begin{array}{l}\text { Synthetic }( \pm)-\left(15 S^{*}, 16 S^{*}\right)-\mathbf{1}^{\mathrm{a}} \\
\delta_{C}\end{array}$ & $\begin{array}{l}\text { Reported } \mathbf{1}^{\mathrm{b}} \\
\delta_{C}\end{array}$ & $\Delta \delta^{\mathrm{c}}$ \\
\hline NH & 8.30 (br s) & 9.10 (br s) & -0.80 & - & - & - \\
\hline 2 & - & - & - & 136.1 & 138.1 & -2.0 \\
\hline 3 & $\begin{array}{l}3.04(\mathrm{ddd}, 14.0,12.0,7.0) \\
2.85(\mathrm{dd}, 14.0,7.0)\end{array}$ & $2.89-2.95(\mathrm{~m})$ & - & 46.8 & 48.4 & -1.6 \\
\hline 6 & $\begin{array}{l}4.25(\mathrm{~d}, 18.0) \\
4.58(\mathrm{~d}, 18.0)\end{array}$ & $\begin{array}{l}3.95(\mathrm{~d}, 17.5) \\
4.73(\mathrm{~d}, 17.5)\end{array}$ & $\begin{array}{l}0.3 \\
-0.15\end{array}$ & 53.4 & 50.4 & 3 \\
\hline 7 & - & - & - & 109.4 & 107.3 & 2.1 \\
\hline 8 & - & - & - & 127.9 & 129.9 & -2.0 \\
\hline 9 & $7.44(\mathrm{~d}, 7.0)$ & 7.46 (br d, 8.0) & -0.02 & 118.5 & 118.5 & 0 \\
\hline 10 & 7.08 (ddd, 8.0, 7.0, 1.0) & 7.18 (ddd, 8.0, 7.5, 1.0) & -0.10 & 119.2 & 119.2 & 0 \\
\hline 11 & $7.20(\mathrm{ddd}, 8.0,7.0,1.0)$ & 7.08 (ddd, 8.0, 7.5, 1.0) & 0.12 & 122.6 & 122.3 & -0.3 \\
\hline 12 & $7.32(\mathrm{ddd}, 7.0,2.0,1.0)$ & 7.33 (br d, 8.0) & -0.01 & 110.4 & 110.3 & -0.1 \\
\hline 13 & - & - & - & 135.3 & 135.2 & 0.1 \\
\hline 14 & $\begin{array}{l}1.87(\text { dddd, } 14.0,12.0,7.0,1.0) \\
2.22(\text { dddd, } 14.0,11.0,7.0,2.0)\end{array}$ & $2.01-2.22(\mathrm{~m})$ & - & 25.0 & 23.4 & 1.6 \\
\hline 15 & $3.35(\mathrm{~d}, 7.0)$ & $3.32(\mathrm{dd}, 3.5,12.0)$ & 0.02 & 44.0 & 43.2 & 0.8 \\
\hline 16 & - & - & - & 76.2 & 74.5 & 1.7 \\
\hline 18 & $1.75(\mathrm{~d}, 8.6)$ & $1.75(\mathrm{ddd}, 6.9,2.5,1.0)$ & 0 & 13.7 & 13.8 & -0.1 \\
\hline 19 & 5.59 (br dq, 7.0, 1.0) & $5.69(\mathrm{q}, 6.9)$ & -0.10 & 122.0 & 124.9 & -2.9 \\
\hline 20 & - & - & - & 136.1 & 134.5 & 1.6 \\
\hline 21 & $\begin{array}{l}3.79(\text { br d, 16.0) } \\
3.64 \text { (br dq, 16.0, 2.0) }\end{array}$ & $\begin{array}{l}3.66(\text { br d, 17.0) } \\
3.58(\text { br d, 17.0) }\end{array}$ & $\begin{array}{l}0.13 \\
0.06\end{array}$ & 55.1 & 53.2 & 1.9 \\
\hline 22 & $1.56(\mathrm{~s})$ & $1.73(\mathrm{~s})$ & -0.17 & 30.1 & 30.2 & -0.1 \\
\hline
\end{tabular}

${ }^{\text {a }}$ Measured in $\mathrm{CDCl}_{3}\left({ }^{1} \mathrm{H}: 500 \mathrm{MHz},{ }^{13} \mathrm{C}: 125 \mathrm{MHz}\right)$

b Measured in $\mathrm{CDCl}_{3}\left({ }^{1} \mathrm{H}: 300 \mathrm{MHz},{ }^{13} \mathrm{C}: 75 \mathrm{MHz}\right)$

c $\Delta \delta(\delta \mathrm{Syn}-\delta \mathrm{Nat})$

occurring 1 was on the opposite face for the tri-substituted exo-cyclic olefin. Accordingly, the relative stereochemistry was anticipated to be the $15 S^{*}, 16 R^{*}$-configuration.

To confirm this consideration, we set about the synthesis of $15 S^{*}, 16 R^{*}$-isomer. The disputed stereocenter was prepared from ketoindole and methyl anion via the FelkinAnh transition state. Therefore, the $R$-configuration could be constructed with methylketone $( \pm)-\mathbf{3 0}$ and indole nucleophile. We search and optimized nucleophilic addition using indole nucleophile. As a result, we found ( $t$ butyldimethylsilyloxy)methyl (TBSOM) group [86-91] protected iodoindole as a suitable compound (Scheme 8). Hence, nucleophilic addition of $\mathbf{3 1}$ with $( \pm)-\mathbf{3 0}$ was converted into $( \pm)-32$ in $97 \%$ yield as a single diastereomer. The planar structure of $( \pm)$-32 was confirmed by $2 \mathrm{D}$ NMR study. Subsequently, global deprotection of ( \pm )-32 obtained $( \pm)-33$ in excellent yields. Following the same reaction sequence as the synthesis of $( \pm)-\left(15 S^{*}, 16 S^{*}\right)-1$ produced $( \pm)-\left(15 S^{*}, 16 R^{*}\right)-\mathbf{1}$. Characterization data provided for synthetic $( \pm)-\left(15 S^{*}, 16 R^{*}\right)-\mathbf{1}$ were fully consistent with the data for the naturally occurring compound reported by Verpoorte and co-workers [17] (Table 3). In addition, an NOE relationship was observed between H-14a and H-22 (i.e., 16-Me) (Fig. 6).

To clarify the cascade reaction mechanism, we attempted the experiment outlined in Scheme 9. At first, to provide the corresponding primary amine, a Staudinger reaction of $( \pm)$-34 with $\mathrm{PPh}_{3}$ was carried out under reflux condition to obtain the piperidine-indole $( \pm)-37$, without acidic activation of the 3-nitropyridinyl group. ESI massmonitoring of the first reaction allowed phosphineimine $\mathbf{3 5}$ to be easily generated from ( \pm -) $\mathbf{3 4}$ and $\mathrm{PPh}_{3}$ without transformation into primary amine via solvolysis. In a timedependent change, phosphineimine smoothly converted to the aminophosphonium cation 36. Though the 3-nitropyridinyl group was a low electrophile, it was unnecessary for acidic activation. We inferred that the 1,3-allylic strain [92] was a key component, occurring via the tri-substituted 


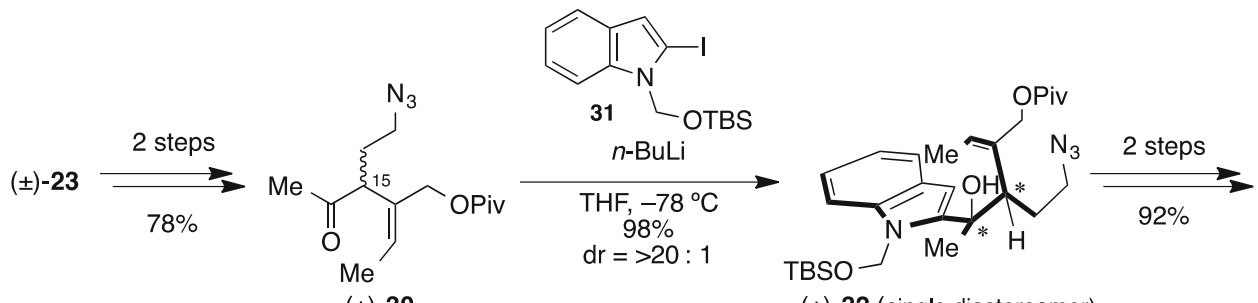

$( \pm)-30$

$( \pm)$-32 (single diastereomer)

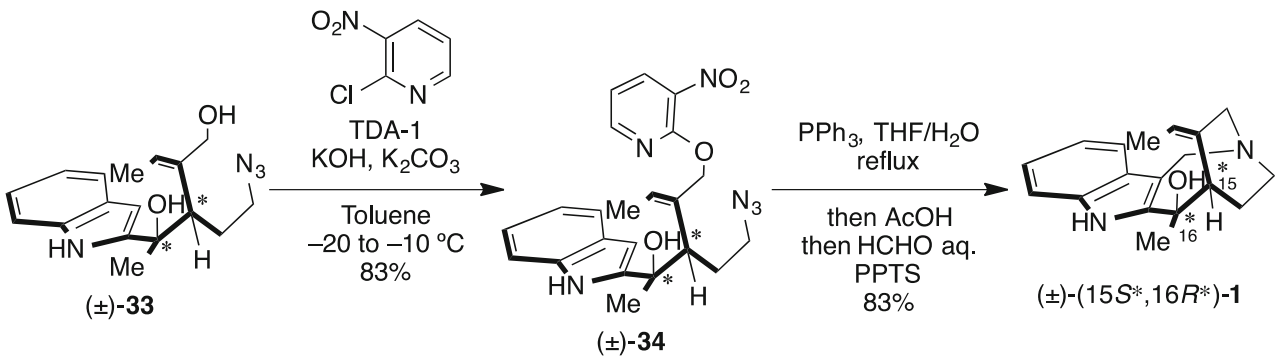

Scheme 8 Total synthesis of $( \pm)-\left(15 S^{*}, 16 R^{*}\right)-\mathbf{1}$

Table 3 Comparison of the NMR data of synthetic $( \pm)-\left(15 S^{*}, 16 R^{*}\right)$-16-hydroxy-16,22-dihydroapparicine; $( \pm)-\left(15 S^{*}, 16 R^{*}\right)$-1 with those reported for the natural product

\begin{tabular}{|c|c|c|c|c|c|c|}
\hline Position & $\begin{array}{l}\text { Synthetic }( \pm)-\left(15 S^{*}, 16 R^{*}\right)-\mathbf{1}^{\mathrm{a}} \\
\delta_{H} \text { (int., mult, } J \text { in Hz) }\end{array}$ & $\begin{array}{l}\text { Reported } \mathbf{1}^{\mathrm{b}} \\
\delta_{H} \text { (int., mult, } J \text { in } \mathrm{Hz} \text { ) }\end{array}$ & $\Delta \delta^{\mathrm{c}}$ & $\begin{array}{l}\text { Synthetic }( \pm)-\left(15 S^{*}, 16 R^{*}\right)-\mathbf{1}^{\mathrm{a}} \\
\delta_{C}\end{array}$ & $\begin{array}{l}\text { Reported } \mathbf{1}^{\mathrm{b}} \\
\delta_{C}\end{array}$ & $\Delta \delta^{\mathrm{c}}$ \\
\hline NH & 8.42 (br s) & 9.10 (br s) & -0.68 & - & - & - \\
\hline 2 & - & - & - & 138.2 & 138.1 & 0.1 \\
\hline 3 & $2.89-2.98(\mathrm{~m})$ & $2.89-2.95(\mathrm{~m})$ & 0 & 48.4 & 48.4 & 0 \\
\hline \multirow[t]{2}{*}{6} & $4.77(\mathrm{~d}, 17.2)$ & $4.73(\mathrm{~d}, 17.5)$ & 0.04 & 50.3 & 50.4 & -0.1 \\
\hline & $3.96(d, 17.2)$ & $3.95(\mathrm{~d}, 17.5)$ & 0.01 & & & \\
\hline 7 & - & - & - & 106.9 & 107.3 & -0.4 \\
\hline 8 & - & - & - & 128.6 & 129.9 & -1.3 \\
\hline 9 & $7.47(\mathrm{~d}, 8.0)$ & 7.46 (br d, 8.0) & 0.01 & 118.5 & 118.5 & 0 \\
\hline 10 & $7.18(\mathrm{dd}, 7.5,7.5)$ & $7.18(\mathrm{ddd}, 8.0,7.5,1.0)$ & 0 & 119.2 & 119.2 & 0 \\
\hline 11 & $7.08(\mathrm{dd}, 7.5,7.5)$ & $7.08(\mathrm{ddd}, 8.0,7.5,1.0)$ & 0 & 122.4 & 122.3 & 0.1 \\
\hline 12 & $7.31(\mathrm{~d}, 8.0)$ & 7.33 (br d, 8.0) & -0.02 & 110.4 & 110.3 & 0.1 \\
\hline 13 & - & - & - & 135.2 & 135.2 & 0 \\
\hline \multirow[t]{2}{*}{14} & $2.17(\mathrm{~m})$ & $2.01-2.22(\mathrm{~m})$ & - & 23.2 & 23.4 & 0.2 \\
\hline & $2.02(\mathrm{~m})$ & & - & & & \\
\hline 15 & $3.31(\mathrm{dd}, 3.2,11.7)$ & $3.32(\mathrm{dd}, 3.5,12.0)$ & -0.01 & 43.1 & 43.2 & -0.1 \\
\hline 16 & - & - & - & 74.5 & 74.5 & 0 \\
\hline 18 & $1.75(\mathrm{~d}, 8.6)$ & $1.75(\mathrm{ddd}, 6.9,2.5,1.0)$ & 0 & 13.8 & 13.8 & 0 \\
\hline 19 & $5.67(\mathrm{q}, 6.9)$ & $5.69(\mathrm{q}, 6.9)$ & -0.02 & 125.2 & 124.9 & 0.3 \\
\hline 20 & - & - & - & 134.1 & 134.5 & -0.4 \\
\hline \multirow[t]{2}{*}{21} & $3.70(\mathrm{~d}, 17.2)$ & $3.66(\mathrm{br} \mathrm{d}, 17.0)$ & 0.04 & 53.1 & 53.2 & 0.1 \\
\hline & $3.52(\mathrm{~d}, 16.6)$ & $3.58(\mathrm{br} \mathrm{d}, 17.0)$ & -0.06 & & & \\
\hline 22 & $1.74(\mathrm{~s})$ & $1.73(\mathrm{~s})$ & 0.01 & 30.1 & 30.2 & -0.1 \\
\hline
\end{tabular}

${ }^{\text {a }}$ Measured in $\mathrm{CDCl}_{3}\left({ }^{1} \mathrm{H}: 500 \mathrm{MHz},{ }^{13} \mathrm{C}: 125 \mathrm{MHz}\right)$

b Measured in $\mathrm{CDCl}_{3}\left({ }^{1} \mathrm{H}: 300 \mathrm{MHz},{ }^{13} \mathrm{C}: 75 \mathrm{MHz}\right)$

${ }^{\mathrm{c}} \Delta \delta(\delta \mathrm{Syn}-\delta \mathrm{Nat})$ 
olefin. Therefore, the 3-nitropyridinyl group was located within close proximity of the phosphineimine group. Subsequent intramolecular Mannich reaction of piperidine-

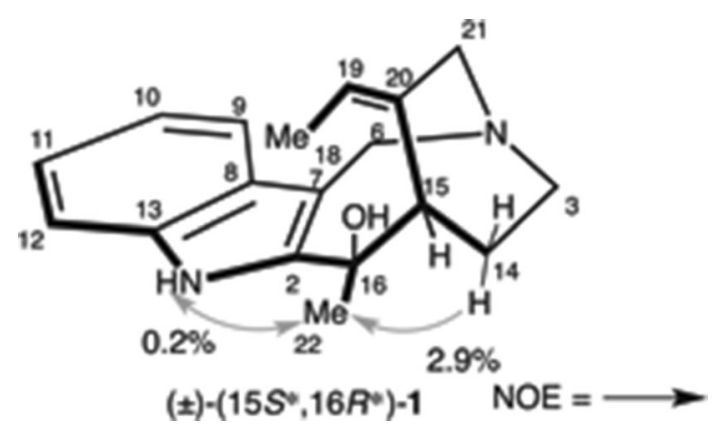

Fig. 6 NOE observations of synthetic $(+)-\left(15 S^{*}, 16 R^{*}\right)-1$ indole $( \pm)$-37 provided $( \pm)-\left(15 S^{*}, 16 R^{*}\right)-\mathbf{1}$ in $43 \%$ yield, using formaldehyde and PPTS. We subsequently expected that the aza-Wittig reaction of $\mathbf{3 6}$ with formaldehyde could assist in generating the iminium cation precursor $\mathbf{3 8}$ in a cascade reaction.

\section{Asymmetric total synthesis of 16-hydroxy-16,22- dihydroapparicine}

We achieved the total synthesis of racemic 16-hydroxy16,22-dihydroapparicine (1) and determined the true relative stereochemistry of the naturally occurring compound. In the next stage, we established the absolute stereochemistry of $\mathbf{1}$. In order to accomplish asymmetric total

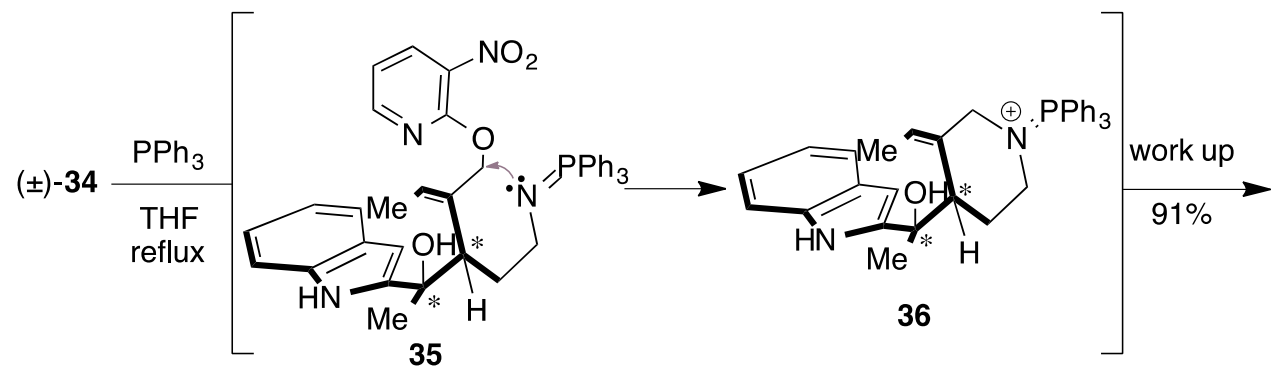

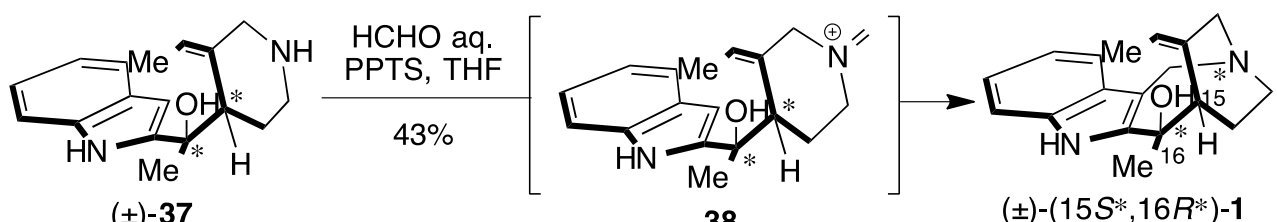

(土)-37

38

$( \pm)-\left(15 S^{*}, 16 R^{*}\right)-1$

Scheme 9 Stepwise synthesis of $( \pm)-\left(15 S^{*}, 16 R^{*}\right)-1$

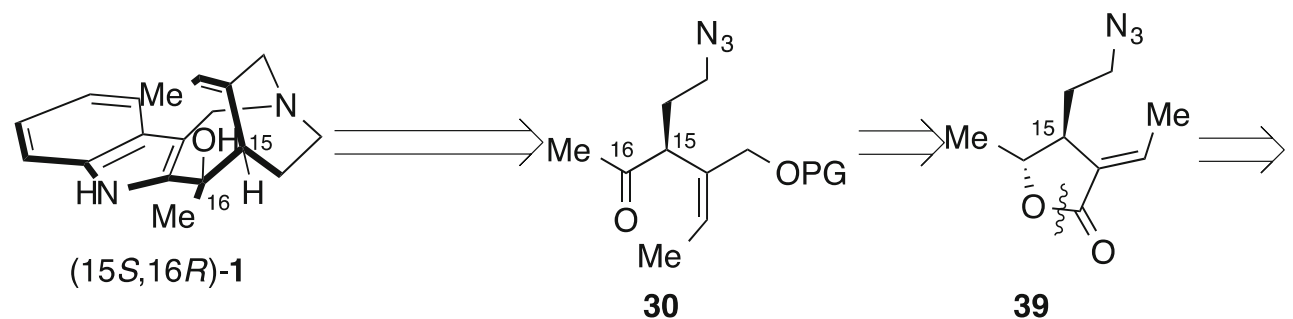

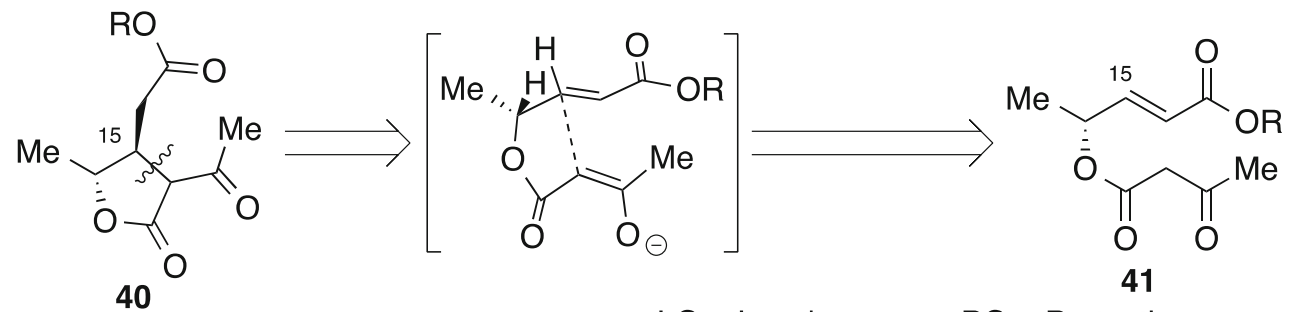

Scheme 10 Asymmetric synthetic plan of $(15 S, 16 R)-1$ 
<smiles>CCOC(=O)C[C@H]1C(C)=COC(=O)[C@@H]1C(C)=O</smiles>

$(+)-41$

(+)-40 (Single diastereomer)

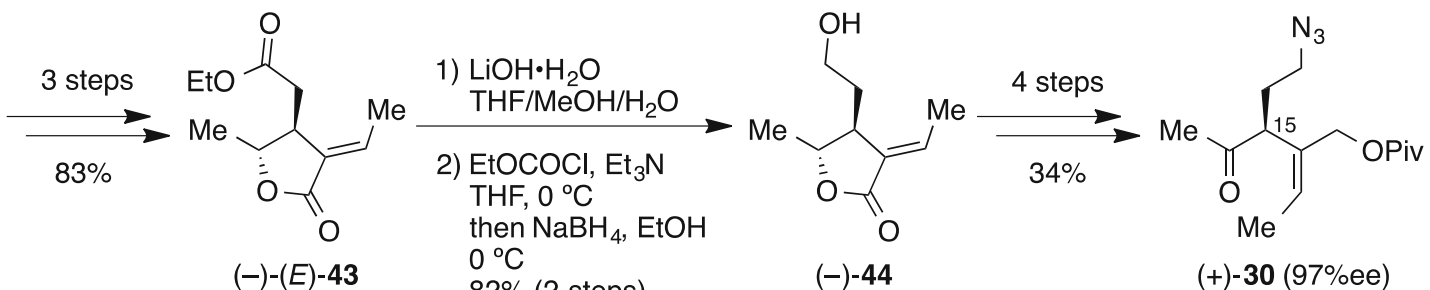

Scheme 11 Asymmetric synthesis of methylketone (+)-30

$(+)-30$<smiles>CC(C)[O+]Cn1c(I)cc2ccccc21</smiles>

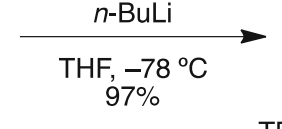
TBSO $(-)-32$
1) $T B A F$ ethylenediamine THF, 95\% $97 \%$ ee 2) DIBAL, $\mathrm{CH}_{2} \mathrm{Cl}_{2}$
$-78^{\circ} \mathrm{C}, 94 \%$

$(-)-33$

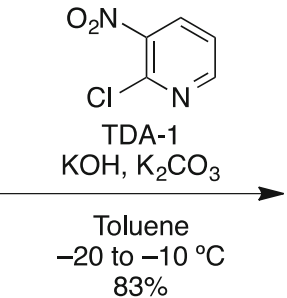

$83 \%$

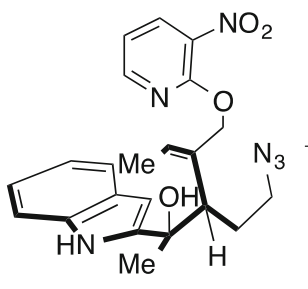

$(-)-34$

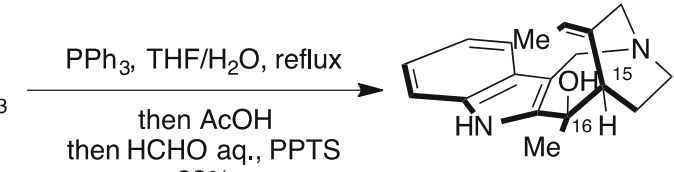

$83 \%$

$(+)-(15 S, 16 R)-1$

Scheme 12 End game of the total synthesis of $(+)-(15 S, 16 R)-1$

synthesis, we used the chiral methylketone $\mathbf{3 0}$ (Scheme 10), which could be supplied from azidobutyrolactone 39, including the appropriate functional groups. If 39 formed acetylbutyrolactone 40, its acetyl and ester moiety could be transformed into $E$-ethylidene and azido groups, respectively. Acetylbutyrolactone $\mathbf{4 0}$ was, therefore, our key intermediate, with synthetic manners for related compounds having already been reported by Smith's group and others [93-96]. We expected that 40 would involve a C-15 stereocenter being constructed by the intramolecular chirality transferring Michael reaction. We expected to perform via 5-exo-cyclization in the ketoester
41, which should be stereo-specifically constructed by the Baldwin rule [97] and Thorpe-Ingold effect [98, 99].

Synthesis of the optically pure tri-substituted $\mathbf{4 0}$ began from commercially available $(-)-(R)$-methyl lactate $\mathbf{4 2}$, which, after with four steps of preparation, provided the ketoester (+)-41 in excellent yield (Scheme 11). With the optically pure (+)-41 in hand, we attempted the intramolecular chirality transferring Michael reaction [100-104]. Through extensive optimization, we found a suitable condition to provide (+)-40 in $91 \%$ yield as a single diastereomer, and assignment of the relative stereochemistry was derived from the coupling constants and 
NOE correlation between $\alpha$ and $\gamma$ protons. The key factor of the intramolecular chirality transferring Michael reaction was the solvent's effect; polar solvent was stabilized to the anticipated transition state. The acetyl group of $(+)-\mathbf{4 0}$ converted into the ethylidene moiety along with the separable $Z$-isomer. The tri-substituted olefin moiety was determined to be of $E$-configuration by NOE correlation. The configuration of the C-3 stereocenter of (-)-43 was determined after simple modification; hydrogenation of (-)-43 obtained a single diastereomer, and the stereochemistry was confirmed to be $S$-configuration by NOE and ROESY correlation. Compound (-)-43 was transformed into primary alcohol $\mathbf{4 4}$ by stepwise preparation; at first, selective hydrolysis of the ethyl ester group under basic condition generated carboxylic acid, followed by the corresponding acid anhydride. The furnished carboxylic anhydride was immediately reduced to the desired (-)-44 in $82 \%$ yield over the two steps [105, 106]. Subsequently, four steps functionalization provided the chiral methylketone (+)-30 in excellent yield without racemization. The optical purity of the (+)-30 (97\%ee) was confirmed by chiral HPLC analysis. The $R$-isomer of (-)-30 was prepared in the same asymmetric synthetic manner from (-)$(S)$-methyl lactate.

Finally, (+)-32 was exposed to the same procedure

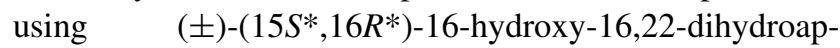
paricine 1 (Scheme 12). The cascade reaction precursor (-)-36 underwent the same cascade reaction condition as that for the synthesis of $( \pm)-\left(15 S^{*}, 16 S^{*}\right)-\mathbf{1}, \quad( \pm)$ $\left(15 S^{*}, 16 R^{*}\right)-1$ to give $(+)-(15 S, 16 R)-1$. Characterization data proved that synthetic $(+)-(15 S, 16 R)-\mathbf{1}$ was fully consistent with the data for the natural compound, as reported

Table 4 Antimalarial activity of synthetic $\mathbf{1}$ and some intermediate compounds

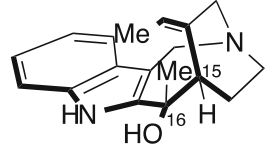

$( \pm)-\left(15 S^{*}, 16 S^{*}\right)-1$

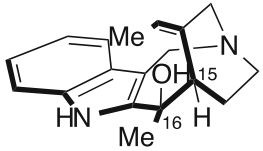

(+)-(15S,16R)-1 and

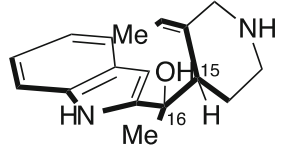

$(-)-(15 S, 16 R)-37$

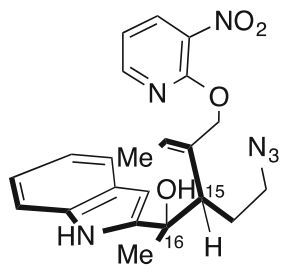

(-)-(15S,16R)-34

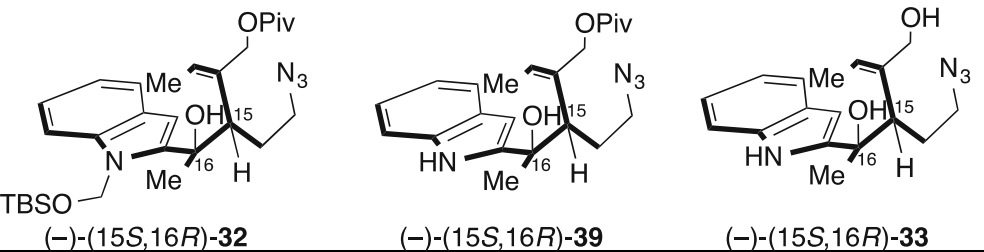

\begin{tabular}{|c|c|c|c|c|c|}
\hline & \multicolumn{5}{|c|}{$\mathrm{IC}_{50}(\mu \mathrm{g} / \mathrm{mL})$} \\
\hline & \multicolumn{2}{|c|}{ Antimalarial activity } & \multirow{2}{*}{$\begin{array}{l}\text { Cytotoxicity } \\
\text { MRC-5 }\end{array}$} & \multicolumn{2}{|c|}{ Selectivity index (SI) } \\
\hline & $\mathrm{K} 1^{\mathrm{a}}$ & $\mathrm{FCR}^{\mathrm{b}}$ & & $\mathrm{M} / \mathrm{K}^{\mathrm{c}}$ & $\mathrm{M} / \mathrm{F}^{\mathrm{d}}$ \\
\hline Tabernaemontana leaf extract & 0.59 & 0.35 & $>25.0$ & $>42.4$ & $>71.4$ \\
\hline Synthetic $( \pm)-\left(15 S^{*}, 16 S^{*}\right)-\mathbf{1}$ & $>12.5$ & ND & 33.3 & $>2.7$ & - \\
\hline Synthetic $(+)-(15 S, 16 R)-\mathbf{1}$ & 9.00 & 8.37 & 51.2 & 5.7 & 6.1 \\
\hline Synthetic (-)-1 & 10.87 & ND & 75.2 & 6.9 & - \\
\hline$(-)-(15 S, 16 R)-32$ & $>12.5$ & $>12.5$ & ND & - & - \\
\hline$(-)-(15 S, 16 R)-39$ & 9.38 & $>12.5$ & 54.0 & 5.8 & $<4.3$ \\
\hline$(-)-(15 S, 16 R)-33$ & 7.58 & 7.17 & 17.8 & 2.3 & 2.5 \\
\hline$(-)-(15 S, 16 R)-34$ & 8.04 & $>12.5$ & $>100.0$ & $>12.4$ & 8.0 \\
\hline$( \pm)-(15 S, 16 R)-37$ & 8.98 & $>12.5$ & 40.8 & 4.5 & $<3.3$ \\
\hline Artemisinin & 0.006 & 0.006 & 45.2 & 7528 & 7528 \\
\hline
\end{tabular}

${ }^{a}$ Chloroquine-resistant strain

b Chloroquine-sensitive strain

c MRC-5/K1

${ }^{d}$ MRC-5/FCR3 
by Verpoorte and co-workers [17]. The optical rotation of synthetic $(+)-(15 S, 16 R)-1,[\alpha]_{\mathrm{D}}^{26}+112.2(c 0.9$, EtOH $)$, compared well with the values reported for the natural sample, $[\alpha]_{\mathrm{D}}^{20}+129(c 0.1, \mathrm{EtOH})$, and the optical rotation of synthetic (-)-(15R,16S)-1, $[\alpha]_{\mathrm{D}}^{26}-104.2(c 0.1, \mathrm{EtOH})$, was prepared in an asymmetric synthetic manner. In addition, an NOE relationship was observed between $\mathrm{H}-14 \mathrm{a}$ and $\mathrm{H}-22$ (i.e., 16-Me). Therefore, the C-16 stereochemistry was determined to be the $R$-configuration.

\section{Biological activity}

Naturally occurring and synthetic compounds were tested for antimalarial activity against Plasmodium falciparum parasites (chloroquine-resistant $\mathrm{K} 1$ strain and chloroquinesusceptible FCR3 strain) and for cytotoxicity (against human MCR-5 cells) [107-109], in comparison with the first-line antimalarial artemisinin.

The in vitro antimalarial activities and cytotoxicities of the naturally occurring and synthetic compounds are summarized in Table 1. As shown in Table 4, Tabernaemontana leaf extract (which includes (+)-(15S,16R)-16hydroxy-16,22-dihydroapparicine) showed activity against both the chloroquine-resistant K1 strain and the chloroquine-sensitive FCR3 strains of Plasmodium falciparum (approximately 78-fold less potent than artemisinin, and with synthetic $( \pm)-\left(15 S^{*}, 16 S^{*}\right)-\mathbf{1}$ having no measurable impact on chloroquine-susceptible parasites). Synthetic $( \pm)-\left(15 S^{*}, 16 S^{*}\right)-\mathbf{1}, \quad(+)-(15 S, 16 R)-\mathbf{1}, \quad(-)-\mathbf{1}$ displayed moderate to weak antimalarial activity (in the range of 9.0 to $>12.5 \mu \mathrm{g} / \mathrm{mL}$ ), while synthetic (-)-1 and intermediaries showed minimal impact ( 7.17 to $>12.5 \mu \mathrm{g} / \mathrm{mL})$. The cytotoxicities against human cells of all synthetic compounds were weak ( $\mathrm{IC}_{50}$ of $17-75 \mu \mathrm{g} / \mathrm{mL}$ ), on average similar to that of artemisinin.

The $\mathrm{IC}_{50}$ value of synthetic (+)-(15S,16R)-1 proved to be significantly lower than the leaf extract containing naturally occurring (+)-(15S,16R)-16-hydroxy-16,22dihydroapparicine.

\section{Conclusion}

We achieved the first total synthesis of $(+)-(15 S, 16 R)-16-$ hydroxy-16,22-dihydroapparicine (1) and the (-)-enantiomer and determined the absolute stereochemistry of naturally occurring $\mathbf{1}$. The synthesis involved a novel cascade reaction for efficient construction of the 1-azabicyclo[4.2.2]decane, including a pseudo-aminal moiety, via a Staudinger reaction, $\mathrm{N}$-allylation, aza-Wittig reaction, and Mannich reaction. In addition, we developed a new method using diastereoselective 1,2-addition of methylketone, using $N$-TBSOM protecting the indole nucleophile and intramolecular chirality transferring Michael reaction with neighboring group participation. In particular, intramolecular chirality transferring Michael reaction proved to be a useful method for synthesis of the chiral tri-substituted butyrolactone. We established an effective enantioselective synthetic route for the production of pseudo-aminal alkaloids.

Synthetic (+)-(15S,16R)-1 exhibited moderate/weak antimalarial activity against chloroquine-resistant Plasmodium falciparum parasites and there is a possibility that the structurally unique compounds may be useful for the development of novel antimalarial drug candidates.

Acknowledgments This work was supported by a grant for the 21 st Century COE Program; a Grant-in-Aid for Young Scientists (22790017) to T.H. from the Ministry of Education, Culture, Sports, Science and Technology (MEXT); and a Kitasato University Research Grant for Young Researchers to T.H. We also thank Dr. Kenichiro Nagai and Ms. Noriko Sato (School of Pharmacy, Kitasato University) for their contributions. We are grateful to Dr. Toh-Seok Kam (University of Malaya) for providing an authentic natural sample of 16-hydroxy-16,22-dihydroapparicine.

Open Access This article is distributed under the terms of the Creative Commons Attribution 4.0 International License (http://crea tivecommons.org/licenses/by/4.0/), which permits unrestricted use, distribution, and reproduction in any medium, provided you give appropriate credit to the original author(s) and the source, provide a link to the Creative Commons license, and indicate if changes were made.

\section{References}

1. Ōmura S (1992) The search for bioactive compounds from microorganisms. Brock/Springer series in contemporary biosciences. Springer-Verlag, New York

2. Ōmura S (2015) Splendid gifts from microorganisms, 5th edn. The Kitasato Institute, Tokyo

3. Ishiyama A, Iwatsuki M, Namatame M, Nishihara-Tsukashima A, Sunazuka T, Takahashi Y, Ömura S, Otoguro K (2011) Borrelidin, a potent antimalarial: stage-specific inhibition profile of synchronized cultures of Plasmodium falciparum. J Antibiot (Tokyo) 64:381-384

4. World Health Organization (WHO) (2014) World malaria report 2014. Available online at: http://www.who.int/malaria/publica tions/world_malaria_report_2014/report/en/. Accessed 1 Apr 2016

5. Ridley RG (2002) Medical need, scientific opportunity and the drive for antimalarial drugs. Nature 415:686-693

6. Greenwood BM, Fidock DA, Kyle DE, Kappe SHI, Alonso PL, Collins FH, Duffy PE (2008) Malaria: progress, perils, and prospects for eradication. J Clin Invest 118:1266-1276

7. Eastman RT, Fidock DA (2009) Artemisinin-based combination therapies: a vital tool in efforts to eliminate malaria. Nat Rev Microbiol 7:864-874

8. Dondorp AM, Nosten F, Yi P, Das D, Phyo AP, Tarning J, Lwin KM, Ariey F, Hanpithakpong W, Lee SJ, Ringwald P, Silamut K, Imwong M, Chotivanich K, Lim P, Herdman T, An SS, Yeung S, Singhasivanon P, Day NPJ, Lindegardh N, Socheat D, White NJ (2009) Artemisinin resistance in Plasmodium falciparum malaria. N Engl J Med 361:455-467 
9. Noedl H, Se Y, Schaecher K, Smith BL, Socheat D, Fukuda MM; Artemisinin Resistance in Cambodia 1 (ARC1) Study Consortium (2008) Evidence of artemisinin-resistant malaria in western Cambodia. N Engl J Med 359:2619-2620

10. White NJ (2008) Qinghaosu (artemisinin): the price of success. Science 320:330-334

11. Ward SA, Sevene EJ, Hastings IM, Nosten F, McGready R (2007) Antimalarial drugs and pregnancy: safety, pharmacokinetics, and pharmacovigilance. Lancet Infect Dis 7:136-144

12. Olliaro P, Wells TN (2009) The global portfolio of new antimalarial medicines under development. Clin Pharmacol Ther 85:584-595

13. Wells TN, Alonso PL, Gutteridge WE (2009) New medicines to improve control and contribute to the eradication of malaria. Nat Rev Drug Discov 8:879-891

14. Rottmann M, McNamara C, Yeung BKS, Lee MCS, Zou B, Russell B, Seitz P, Plouffe DM, Dharia NV, Tan J, Cohen SB, Spencer KR, González-Páez GE, Lakshminarayana SB, Goh A, Suwanarusk R, Jegla T, Schmitt EK, Beck HP, Brun R, Nosten F, Renia L, Dartois V, Keller TH, Fidock DA, Winzeler EA, Diagana TT (2010) Spiroindolones, a potent compound class for the treatment of Malaria. Science 329:1175-1180

15. Winzeler EA (2008) Malaria research in the post-genomic era. Nature 455:751-756

16. Ioset JR (2008) Natural products for neglected diseases: a review. Curr Org Chem 12:643-666

17. Perera P, van Beek TA, Verpoorte R (1984) 16(S)-Hydroxy16,22-dihydroapparicine, a new alkaloid from the leaves of Tabernaemontana dichotoma. J Nat Prod 47:835-838

18. Noguchi Y, Hirose T, Furuya Y, Ishiyama A, Otoguro K, Ōmura S, Sunazuka T (2012) The first total synthesis and reassignment of the relative stereochemistry of 16-hydroxy-16,22-dihydroapparicine. Tetrahedron Lett 53:1802-1807

19. Hirose T, Noguchi $Y$, Furuya $Y$, Ishiyama A, Iwatsuki M, Otoguro K, Ōmura S, Sunazuka T (2013) Structure determination and total synthesis of (+)-16-hydroxy-16,22-dihydroapparicine. Chem Eur J 19:10741-10750

20. Gilbert B, Duarte AP, Nakagawa Y, Joule JA, Flores SE, Aguayo Brissolese J, Campello J, Carrazzoni EP, Owellen RJ, Blossey EC, Brown KS Jr, Djerassi C (1965) Alkaloid studies. L. The alkaloids of twelve Aspidosperma species. Tetrahedron 21:1141-1166

21. Joule JA, Monteiro H, Durham LJ, Gilbert B, Djerassi C (1965) Alkaloid studies. 48. The structure of apparicine, a novel Aspidosperma alkaloid. J Chem Soc Perkin 1 4773-4780

22. Akhter L, Brown RT, Moorcroft D (1978) 10-Hydroxy- and 10-methoxyapparicine: two new alkaloids from Ochrosia oppositifolia. Tetrahedron Lett 19:4137-4140

23. Atta-ur-Rahman, Muzaffar A (1985) The isolation and structure of ervaticine, a new indole alkaloid from Ervatamia coronaria. Heterocycles 23:2975-2978

24. Kam TS, Pang HS, Choo YM, Komiyama K (2004) Biologically active ibogan and vallesamine derivatives from Tabernaemontana divaricata. Chem Biodivers 1:646-656

25. Michel S, Tillequin F, Koch M (1986) Brafouédine et Isobrafouédine: nouveaux alcaloïdes indoliques mineurs de Strychnos dinklagei. J Nat Prod 49:452-455

26. Pawelka KH, Stöckigt J, Danieli B (1986) Epchrosine-a new indole alkaloid isolated from plant cell cultures of Ochrosia elliptica Labill. Plant Cell Rep 5:147-149

27. Walser A, Djerassi C (1964) Alkaloid-studien XLIX die strukturen von Vallesamin und $O$-acetyl-vallesamin. Helv Chim Acta 47:2072-2086

28. Atta-ur-Rahman, Alvi KA, Abbas SA, Voelter W (1987) Isolation of 19,20-Z-vallesamine and 19,20-E-vallesamine from $\mathrm{Al}$ stonia scholaris. Heterocycles 26:413-419
29. Zeches M, Ravao T, Richard B, Massiot G, Le Men-Olivier L, Verpoorte R (1987) Some new vallesamine-type alkaloids. J Nat Prod 50:714-720

30. Yamauchi T, Abe F, Padolina WG, Dayrit FM (1990) Alkaloids from leaves and bark of Alstonia scholaris in the Philippines. Phytochemistry 29:3321-3325

31. Ku WF, Tan SJ, Low YY, Komiyama K, Kam TS (2011) Angustilobine and andranginine type indole alkaloids and an uleine-secovallesamine bisindole alkaloid from Alstonia angustiloba. Phytochemistry 72:2212-2218

32. Macabeo APG, Krohn K, Gehle D, Read RW, Brophy JJ, Cordell GA, Franzblau SG, Aguinaldo AM (2005) Indole alkaloids from the leaves of Philippine Alstonia scholaris. Phytochemistry 66:1158-1162

33. van Beek TA, Deelder AM, Verpoorte R, Svendsen AB (1984) Antimicrobial, antiamoebic and antiviral screening of some Tabernaemontana species. Planta Med 50:180-185

34. van Beek TA, Verpoorte R, Svendsen AB, Fokkens R (1985) Antimicrobially active alkaloids from Tabernaemontana chippii. J Nat Prod 48:400-423

35. van der Heijden R, Brouwer RL, Verpoorte R, van Beek TA, Harkes PAA, Svendsen AB (1986) Indole alkaloids from Tabernaemontana elegans. Planta Med 52:144-147

36. Ingkaninan K, Ijzerman AP, Taesotikul T, Verpoorte R (1999) Isolation of opioid-active compounds from Tabernaemontana pachysiphon leaves. J Pharm Pharmacol 51:1441-1446

37. Tarselli MA, Raehal KM, Brasher AK, Streicher JM, Groer CE, Cameron MD, Bohn LM, Micalizio GC (2011) Synthesis of conolidine, a potent non-opioid analgesic for tonic and persistent pain. Nat Chem 3:449-453

38. Lim KH, Low YY, Kam TS (2006) Biomimetic oxidative transformations of pericine: partial synthesis of apparicine and valparicine, a new pentacyclic indole alkaloid from Kopsia. Tetrahedron Lett 47:5037-5039

39. Bennasar ML, Zulaica E, Solé D, Alonso S (2009) The first total synthesis of $( \pm)$-apparicine. Chem Commun (23):3372-3374

40. Bennasar ML, Zulaica E, Solé D, Roca T, García-Díaz D, Alonso S (2009) Total synthesis of the bridged indole alkaloid apparicine. J Org Chem 74:8359-8368

41. Takanashi N, Suzuki K, Kitajima M, Takayama H (2016) Total synthesis of conolidine and apparicine. Tetrahedron Lett 57:375-378

42. Scopes DIC, Allen MS, Hignett GJ, Wilson NDV, Harris M, Joule JA (1977) A synthetic approach to the indole alkaloid apparicine. Synthesis of the ring skeleton. J Chem Soc Perkin Trans 1 (21):2376-2385

43. Kettle JG, Roberts D, Joule JA (2010) Synthesis of 1,2,3,4,5,7hexahydro- $6 H$-azocino[4,3- $b$ ]indol-6-ones as intermediates for the synthesis of apparicine. Heterocycles 82:349-370

44. Chauhan PS, Weinreb SM (2014) Convergent approach to the tetracyclic core of the apparicine class of indole alkaloids via a key intermolecular nitrosoalkene conjugate addition. J Org Chem 79:6389-6393

45. Martin CL, Nakamura S, Otte R, Overman LE (2011) Total synthesis of (+)-condylocarpine, (+)-isocondylocarpine, and (+)-tubotaiwine. Org Lett 13:138-141

46. Hurt CR, Lin R, Rapoport H (1999) Enantiospecific synthesis of $(R)$-4-amino-5-oxo-1,3,4,5-tetrahydrobenz $[c d]$ indole, an advanced intermediate containing the tricyclic core of the ergots. J Org Chem 64:225-233

47. Hart DJ, Magomedov N (1999) Spiroquinazoline support studies: new cascade reactions based on the Morin rearrangement. J Org Chem 64:2990-2991

48. Wada Y, Nagasaki H, Tokuda M, Orito K (2007) Synthesis of $\mathrm{N}$-protected staurosporinones. J Org Chem 72:2008-2014 
49. Diker K, Döéde Maindreville M, Royer D, Provost FL, Lévy J (1999) The gramine route to the Diels-Alder adducts of indolo2,3-quinodimethanes. Tetrahedron Lett 40:7463-7467

50. Somei M, Karasawa Y, Kaneko C (1981) Selective monoalkylation of carbon nucleophiles with gramine. Heterocycles 16:941-949

51. Freed JD, Hart DJ, Magomedov NA (2001) Trapping of the putative cationic intermediate in the Morin rearrangement with carbon nucleophiles. J Org Chem 66:839-852

52. Low KH, Magomedov NA (2005) Phosphine-mediated coupling of gramines with aldehydes: a remarkably simple synthesis of 3-vinylindoles. Org Lett 7:2003-2005

53. Grubbs AW, Artman GD 3rd, Tsukamoto S, Williams RM (2007) A concise total synthesis of the notoamides C and D. Angew Chem Int Ed Engl 46:2257-2261

54. Artman GD 3rd, Grubbs AW, Williams RM (2007) Concise, asymmetric, stereocontrolled total synthesis of stephacidins A, B and notoamide B. J Am Chem Soc 129:6336-6342

55. Dubey R, Olenyuk B (2010) Direct organocatalytic coupling of carboxylated piperazine-2,5-diones with indoles through conjugate addition of carbon nucleophiles to indolenine intermediates. Tetrahedron Lett 51:609-612

56. de la Herrán G, Segura A, Csákÿ AG (2007) Benzylic substitution of gramines with boronic acids and rhodium or iridium catalysts. Org Lett 9:961-964

57. Csomós P, Fodor L, Sohár P, Bernáth G (2005) Synthesis of thiazino[6,5-b]indole derivatives, analogues of the phytoalexin cyclobrassinin. A new method for preparation of 3-aminomethylindole. Tetrahedron 61:9257-9262

58. Kennedy AR, Taday MH, Rainier JD (2001) The use of sulfur ylides in the synthesis of substituted indoles. Org Lett 3:2407-2409

59. Nishimura T, Yamada K, Takebe T, Yokoshima S, Fukuyama T (2008) (1-Nosyl-5-nitroindol-3-yl)methyl ester: a novel protective group for carboxylic acids. Org Lett 10:2601-2604

60. Shinohara H, Fukuda T, Iwao M (1999) A formal synthesis of optically active clavicipitic acids, unusual azepinoindole-type ergot alkaloids. Tetrahedron 55:10989-11000

61. Jones DT, Artman GD 3rd, Williams RM (2007) Coupling of activated esters to gramines in the presence of ethyl propiolate under mild conditions. Tetrahedron Lett 48:1291-1294

62. Staudinger H, Meyer J (1919) Über neue organische Phosphorverbindungen III. Phosphinmethylenderivate und Phosphinimine. Helv Chim Acta 2:635-646

63. Zimmer H, Singh G (1963) Synthesis of some triphenylphosphinalkylimines and mono- and dialkylaminotriphenylphosphonium halides. J Org Chem 28:483-486

64. Zimmer H, Jayawant M, Gutsch P (1970) Synthesis of secondary amines via triphenylphosphine imines. J Org Chem $35: 2826-2828$

65. Briggs EM, Brown GW, Jiricny J, Meidine MF (1980) Synthetic uses of iminophosphoranes. Monoalkylation of primary aromatic amines. Synthesis 1980:295-296

66. Frøyen P, Skramstad J (1998) Phosphorus in organic synthesis. The Tanigawa reaction revisited as a method for converting alcohols to tertiary amines. Tetrahedron Lett 39:6387-6390

67. Chérest M, Felkin H, Prudent N (1968) Torsional strain involving partial bonds. The stereochemistry of the lithium aluminium hydride reduction of some simple open-chain ketones. Tetrahedron Lett 9:2199-2204

68. Anh NT (1980) Regio- and stereo-selectivities in some nucleophilic reactions. Top Curr Chem 88:145-162

69. Anh NT, Eisenstein O (1977) Theoretical interpretation of 1-2 asymmetric induction-importance of anti-periplanarity. Nouv $\mathrm{J}$ Chim 1:61-70
70. Anh NT, Eisenstein O (1976) Induction asymetrique 1-2: comparaison ab initio des modeles de cram, de cornforth, de Karabatsos et de felkin. Tetrahedron Lett 17:155-158

71. Mengel A, Reiser O (1999) Around and beyond Cram's rule. Chem Rev 99:1191-1224

72. Dambacher J, Anness R, Pollock P, Bergdahl M (2004) Highly diastereoselective conjugate additions of monoorganocopper reagents to chiral imides. Tetrahedron 60:2097-2110

73. Martinelli MJ (1990) Asymmetric Diels-Alder reaction with $\gamma$ functionalized $\alpha, \beta$-unsaturated chiral $N$-acyloxazolidinones: synthesis of (+)-S-145. J Org Chem 55:5065-5073

74. Sundberg RJ, Russell HF (1973) Syntheses with $N$-protected 2-lithioindoles. J Org Chem 38:3324-3330

75. Mahboobi S, Uecker A, Sellmer A, Cénac C, Höcher H, Pongratz H, Eichhorn E, Hufsky H, Trümpler A, Sicker M, Heidel F, Fischer T, Stocking C, Elz S, Böhmer FD, Dove S (2006) Novel bis(1H-indol-2-yl)methanones as potent inhibitors of FLT3 and platelet-derived growth factor receptor tyrosine kinase. J Med Chem 49:3101-3115

76. Naka H, Akagi Y, Yamada K, Imahori T, Kasahara T, Kondo Y (2007) Fluorous synthesis of Yuehchukene by $\alpha$-lithiation of perfluoroalkyl-tagged 1-(arylsulfonyl)indole with mesityllithium. Eur J Org Chem (28):4635-4637

77. Mahboobi S, Uecker A, Cénac C, Sellmer A, Eichhorn E, Elz S, Böhmer FD, Dove S (2007) Inhibition of FLT3 and PDGFR tyrosine kinase activity by bis(benzo[b]furan-2-yl)methanones. Bioorg Med Chem 15:2187-2197

78. Bourderioux A, Kassis P, Mérour JY, Routier S (2008) Synthesis of new fused and substituted benzo and pyrido carbazoles via C-2 (het)arylindoles. Tetrahedron 64:11012-11019

79. So CM, Yeung CC, Lau CP, Kwong FY (2008) A new family of tunable indolylphosphine ligands by one-pot assembly and their applications in Suzuki-Miyaura coupling of aryl chlorides. J Org Chem 73:7803-7806

80. Noguchi-Yachide T, Tetsuhashi M, Aoyama H, Hashimoto Y (2009) Enhancement of chemically-induced HL-60 cell differentiation by $3,3^{\prime}$-diindolylmethane derivatives. Chem Pharm Bull 57:536-540

81. Denton JR (2010) One-pot desulfonylative alkylation of $N$-sulfonyl azacycles using alkoxides generated by phase-transfer catalysis. Synthesis (5):775-782

82. Yasukochi T, Inaba C, Fukase K, Kusumoto S (1999) Nitropyridyl glycosides: new glycosyl donors for enzymatic transglycosylation. Tetrahedron Lett 40:6585-6589

83. Yasukochi T, Fukase K, Kusumoto S (1999) 3-Nitro-2-pyridyl glycoside as donor for chemical glycosylation and its application to chemoenzymatic synthesis of oligosaccharide. Tetrahedron Lett 40:6591-6593

84. Ballesteros P, Claramunt RM (1987) Study of the catalytic properties of tris(3,6-dioxaheptyl) amine (TDA-1) in heteroaromatic nucleophilic substitution of chloropyridines and their $n$-oxides. Tetrahedron 43:2557-2564

85. Nakano M, Kikuchi W, Matsuo JI, Mukaiyama T (2001) An efficient method for the $p$-methoxybenzylation of hydroxy group with 2-(4-methoxybenzyloxy)-3-nitropyridine. Chem Lett 30:424-425

86. Benneche T, Gundersen LL, Undheim K (1988) (tertButyldimethylsilyloxy)methyl chloride: synthesis and use as $\mathrm{N}$ protecting group in pyrimidinones. Acta Chem Scand B 42:384-389

87. Gundersen LL, Benneche T, Undheim K (1989) Chloromethoxysilanes as protecting reagents for sterically hindered alcohols. Acta Chem Scand 43:706-709

88. Pitsch S, Weiss PA, Wu X, Ackermann D, Honegger T (1999) Fast and reliable automated synthesis of RNA and partially $2^{\prime}$ $O$-protected precursors ('caged RNA') based on two novel, 
orthogonal $2^{\prime}-O$-protecting groups. Helv Chim Acta 82:1753-1761

89. Pitsch S, Weiss PA, Jenny L, Stutz A, Wu X (2001) Reliable chemical synthesis of oligoribonucleotides (RNA) with $2^{\prime}-O$ [(triisopropylsilyl)oxy]methyl(2'-O-tom)-protected phosphoramidites. Helv Chim Acta 84:3773-3795

90. Zajac MA, Vedejs E (2004) A synthesis of the diazonamide heteroaromatic biaryl macrocycle/hemiaminal core. Org Lett 6:237-240

91. Attaluri S, Bonala RR, Yang IY, Lukin MA, Wen Y, Grollman AP, Moriya M, Iden CR, Johnson F (2010) DNA adducts of aristolochic acid II: total synthesis and site-specific mutagenesis studies in mammalian cells. Nucleic Acid Res 38:339-352

92. Hoffmann RW (1989) Allylic 1,3-strain as a controlling factor in stereoselective transformations. Chem Rev 89:1841-1860

93. Smith AB III, Sestelo JP, Dormer PG (1995) Total synthesis of (-)-furaquinocin C. J Am Chem Soc 117:10755-10756

94. Sestelo JP, Dormer PG (2000) A highly efficient synthetic route to (-)-furaquinocin C. Heterocycles 52:1315-1328

95. Greatrex BW, Kimber MC, Taylor DK, Fallon G, Tiekink ER (2002) 1,2-Dioxines as masked cis $\gamma$-hydroxy enones and their versatility in the synthesis of highly substituted $\gamma$-lactones. J Org Chem 67:5307-5314

96. Peña-López M, Martínez MM, Sarandeses LA, Pérez Sestelo J (2009) Total synthesis of (+)-neomarinone. Chem Eur J 15:910-916

97. Baldwin JE (1976) Rules for ring closure. J Chem Soc Chem Commun (18):734-736

98. Jung ME, Gervay J (1989) Solvent effects in intramolecular Diels-Alder reactions of 2-furfuryl methyl fumarates: evidence for a polar transition state. J Am Chem Soc 111:5469-5470

99. Yorimitsu H, Nakamura T, Shinokubo H, Oshima K, Omoto K, Fujimoto H (2000) Powerful solvent effect of water in radical reaction: triethylborane-induced atom-transfer radical cyclization in water. J Am Chem Soc 122:11041-11047

100. Li TT, Wu YL (1988) An approach to forskolin an efficient synthesis of a tricyclic lactone intermediate. Tetrahedron Lett 29:4039-4040
101. Somoza C, Darias J, Rúveda EA (1989) Intramolecular Michael-aldol condensation approach to the construction of advanced intermediates in the synthesis of forskolin. J Org Chem 54:1539-1543

102. Little RD, Masjedizadeh MR, Wallquist O, McLoughlin JI (1995) The intramolecular Michael reaction. Org React 47:315-552

103. Bacigaluppo JA, Colombo MI, Preite MD, Zinczuk J, Rúveda EA (1996) The Michael-aldol condensation approach to the construction of key intermediates in the synthesis of nimbolide and nagilactone A. Synth Commun 26:2737-2749

104. Uchida K, Ishigami K, Watanabe H, Kitahara T (2007) Synthesis of an insecticidal tetrahydroisocoumarin, $(3 R, 4 S, 4 \mathrm{a} R)-4,8$ dihydroxy-3-methyl-3,4,4a,5-tetrahydro-1 $H$-2-benzopyran-1one. Tetrahedron 63:1281-1287

105. Crow JR, Thomson RJ, Mander LN (2006) Synthesis and confirmation of structure for the gibberellin $\mathrm{GA}_{131}$ (18-hydroxy$\mathrm{GA}_{4}$ ). Org Biomol Chem 4:2532-2544

106. Lainchbury MD, Medley MI, Taylor PM, Hirst P, Dohle W, Booker-Milburn KI (2008) A protecting group free synthesis of $( \pm)$-neostenine via the $[5+2]$ photocycloaddition of maleimides. J Org Chem 73:6497-6505

107. Otoguro K, Kohana A, Manabe C, Ishiyama A, Ui H, Shiomi K, Yamada H, Ōmura S (2001) Potent antimalarial activities of polyether antibiotic, X-206. J Antibiot 54:658-663

108. Otoguro K, Ishiyama A, Ui H, Kobayashi M, Manabe C, Yan G, Takahashi Y, Tanaka H, Yamada H, Ōmura S (2002) In vitro and in vivo antimalarial activities of the monoglycoside polyether antibiotic, K-41 against drug resistant strains of Plasmodia. J Antibiot 55:832-834

109. Iwatsuki M, Takada S, Mori M, Ishiyama A, Namatame M, Nishihara-Tsukashima A, Nonaka K, Masuma R, Otoguro K, Shiomi K, Ōmura S (2011) In vitro and in vivo antimalarial activity of puberulic acid and its new analogs, viticolins A-C, produced by Penicillium sp. FKI-4410. J Antibiot 64:183-188 